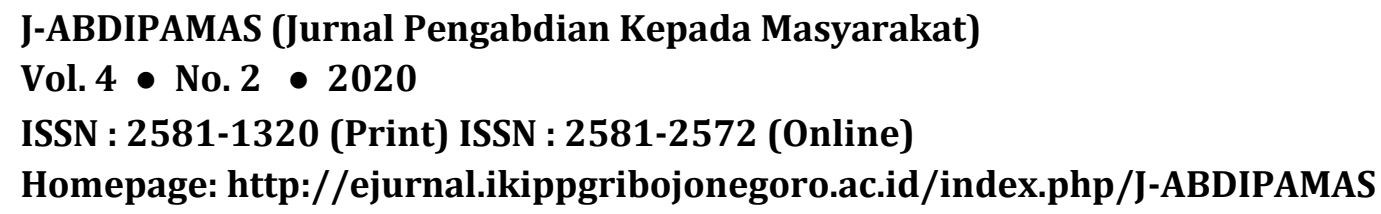

ISSN : 2581-1320 (Print) ISSN : 2581-2572 (Online)

Homepage: http://ejurnal.ikippgribojonegoro.ac.id/index.php/J-ABDIPAMAS

\title{
PENINGKATAN PRODUKTIVITAS UMKM KOPI MURIA MELALUI PELATIHAN PENGOLAHAN KOPI
}

\author{
Khusna Dwijayanti ${ }^{1}$, Noor Azizah ${ }^{2}$, Mahmudatus Sa'diyah ${ }^{3}$ \\ ${ }^{1}$ UNISNU Jepara. Email: khusna.dwijayanti@gmail.com \\ 2UNISNU Jepara. Email: azizah@unisnu.ac.id \\ 3UNISNU Jepara. Email: mahdah@unisnu.ac.id
}

\begin{abstract}
Today's muria coffee has a universal appeal to many people from different walks of life. Coffee lovers in Indonesia and abroad are also increasing. This triggered to develop the production of coffee muria as a regional superior product that should be lifted nationally. The problems faced by the perpetrators of SMEs coffee martia is the post-harvest processing of coffee, from the stage of sorting coffee, roasting, grinding, packaging, until the technique of coffee marketing. The purpose of this activity is to advance the muria coffee SMEs by educating SME players through coffee processing training and improving the coffee production process from manual to automatic using machines. The target of this activity was the coffee SMEs in Colo village, Dawe district. The method is done by giving machines and training on coffee processing. The output of this community service activity is the increasing in productivity of muria coffee from $3 \mathrm{~kg} /$ day to $15 \mathrm{~kg}$ / day. In addition, through coffee processing training, the quality of coffee is increasing by the uniformity of roasted coffee been, by using a roasting machine. Therefore, this activity is expected to encourage muria coffee products as the regional superior products.
\end{abstract}

Keywords: coffee, muria, productivity, umkm

\section{ABSTRAK}

Saat ini kopi muria memiliki daya tarik universal bagi banyak orang dari berbagai lapisan masyarakat. Penikmat kopi di Indonesia maupun mancanegara juga terus meningkat. Hal tersebut memicu untuk mengembangkan produksi kopi muria sebagai produk unggulan daerah yang patut di angkat secara nasional. Permasalahan yang dihadapi oleh pelaku UMKM kopi muria adalah pengolahan pasca panen kopi, mulai tahap penyortiran kopi, roasting, grinding, packaging, sampai pada teknik pemasaran kopi. Tujuan kegiatan ini adalah memajukan UMKM kopi muria dengan melakukan edukasi kepada pelaku UMKM melalui kegiatan pelatihan pengolahan kopi dan perbaikan proses produksi kopi dari manual menjadi otomatis menggunakan mesin. Sasaran kegiatan ini adalah para pelaku UMKM kopi di kelurahan Colo kecamatan Dawe. Metode kegiatan dilakukan dengan cara pemberian mesin dan pelatihan pengolahan kopi. Luaran dari kegiatan pengabdian kepada masyarakat ini adalah meningkatnya produktivitas UMKM kopi muria dari $3 \mathrm{~kg} /$ hari menjadi $15 \mathrm{~kg} / \mathrm{hari}$. Selain itu melalui pelatihan pengolahan kopi, dihasilkan peningkatan kualitas kopi yaitu hasil kematangan biji kopi sangrai yang seragam, dengan penggunaan mesin penyangrai kopi. Oleh karena itu, kegiatan ini diharapkan dapat mendorong produk kopi muria sebagai produk unggulan daerah.

Kata Kunci: kopi, muria, produktivitas, umkm

\section{PENDAHULUAN}

Pemerintah Kabupaten Kudus telah menetapkan beberapa komoditas unggulan daerah untuk dikembangkan di Kabupaten Kudus yaitu jenang, batik, kerajinan bordir, 
dan kopi muria. Kebijakan Pemerintah Kabupaten Kudus untuk memasukkan kopi muria sebagai salah satu komuditas unggulan daerah merupakan langkah yang tepat.

Kopi muria sendiri memiliki daya tarik universal bagi banyak orang dari berbagai lapisan masyarakat. Selain itu, saat ini penikmat kopi semakin meningkat. Hal tersebut dibuktikan dengan banyaknya kafe atau kedai kopi yang banyak di dirikan. Saat ini luas lahan kopi yang di lereng Muria mencapai 621 hektare, meliputi wilayah Colo, Japan, Ternadi, Kajar, Rahtawu, dan Menawan. (Data Dinas Pertanian dan Pangan Kabupaten Kudus, 2016). Dan mayoritas kopi yang dibudidayakan adalah kopi jenis robusta.

Tanaman kopi (Coffea sp.) merupakan salah satu tanaman perkebunan yang telah menjadi komoditas yang diperhitungkan dalam penguatan devisa negara. Tanaman kopi (Coffea sp.) merupakan salah satu tanaman perkebunan yang telah menjadi komoditas yang diperhitungkan dalam penguatan devisa negara.

Tanaman kopi merupakan salah satu tanaman perkebunan yang telah menjadi komoditas yang diperhitungkan dalam penguatan devisa negara. (Muhammad Fuad Anshori, 2014.) Di Indonesia, sebagian kopi bubuk yang dihasilkan adalah jenis kopi Robusta, karena mempunyai sifat yang lebih unggul dan sangat cepat berkembang (Irma Nopitasari, 2010). Hal inilah yang mendorong petani kopi Muria menanam jenis kopi Robusta. Namun, kualitas kopi Robusta lebih rendah daripada kopi Arabika, dengan berat rendemen 18\%. (Irma Nopitasari, 2010).

Kopi mempunyai kandungan caffein yang dapat menstimulasi susunan syaraf pusat (Hendra Budiman, dkk, 2010). Kopi mengandung berbagai senyawa antioksidan yang berguna bagi tubuh. Beberapa contoh senyawa antioksidan dalam kopi antara lain kafein, polifenol, flavonoid, proantosianidin, kumarin, asam klorogenat, dan tokoferol. (Muhammad Ridwan Harahap, 2017).

Wilayah Desa Colo Muria memiliki lahan sekitar 100 hektare dimana untuk tiap hektare nya mampu memanen biji kopi rata-rata 9 ton untuk tiap kali panen. Jumlah perajin kopi muria sekitar 10 UMKM khusus di wilayah Desa Colo. Dari tahun ke tahun luas lahan tanaman kopi terus meningkat seperti yang tersajikan pada tabel 1.

Tabel 1. Luas tanam tanaman perkebunan di Kabupaten Kudus, 2011-2015 (Ha)

\begin{tabular}{lll}
\hline Tahun & Kopi Arabica & Kopi Robusta \\
\hline 2011 & 16,85 & 524,55 \\
\hline 2012 & 15,05 & 531,12 \\
\hline 2013 & 15,65 & 572,59 \\
\hline 2014 & 16,50 & 578,31 \\
\hline 2015 & 17,65 & 604,11 \\
\hline
\end{tabular}

Sumber : Kabupaten Kudus dalam Angka 2016 (BPS)

Tahap pengolahan kopi diawali dengan menyortir biji kopi mentah, kemudian menyangrai sampai matang, dan menggiling biji kopi menjadi kopi bubuk. Untuk produksi kopi di wilayah lereng muria, rata-rata setiap hektare mampu menghasilkan kopi mentah sebanyak tiga sampai empat ton, sedangkan harga green beans saat ini ratarata sekitar Rp 30.000 per kg. Oleh sebab itu, jumlah produksi tiap tahun khususnya di wilayah Colo Dawe Kudus terus mengalami peningkatan seperti tergambar pada Tabel 
2. Peningkatan jumlah produksi dikarenakan jumlah permintaan dari konsumen meningkat.

Tabel 2. Produksi kopi dirinci menurut kecamatan di kabupaten Kudus, (ton)

\begin{tabular}{ccc}
\hline Tahun & Kec. Gebog & Kec. Dawe \\
\hline 2011 & 67,22 & 128,39 \\
\hline 2012 & 87,32 & 147,49 \\
\hline 2013 & 90,30 & 178,12 \\
\hline 2014 & 96,34 & 180,40 \\
\hline 2015 & 126,97 & 226,78
\end{tabular}

Sumber : Kabupaten Kudus dalam Angka 2016 (BPS)

Untuk aspek pemasaran masih dilakukan secara tradisional dengan menjualkan produk kopi muria di kios-kios sekitar desa Colo atau Kudus dan terkadang melayani pemesanan dari berbagai daerah sebagai oleh-oleh khas kabupaten Kudus.

UMKM Kopi Muria yang menjadi mitra kami ada 3, yaitu, UMKM Wilhelmina, UMKM You Soeka, dan UMKM Langgeng. Kondisi ketiga mitra ini berbeda semua. Adapun kondisi existing mitra adalah sebagai berikut :

a. UMKM Wilhelmina

1. Peralatan Produksi

Sudah menggunakan mesin untuk proses menyangrai dan menggiling kopi

2. Jenis Produksi

Kopi Robusta dan Arabica

Jenis dari kopi muria ini dibagi menjadi 3 grade, yaitu:

a) Grade A merupakan hasil sortiran pertama

b) Grade B merupakan hasil sortiran kedua

c) Grade C merupakan hasil sortiran ketiga

3. Kapasitas Produksi

$150 \mathrm{~kg} /$ bulan

b. UMKM You Soeka

1. Peralatan Produksi

Belum memiliki peralatan untuk proses penggilingan, penyaringan, dan penyangraian.

Selama ini proses penggilingan dan penyaringan bubuk kopi dengan cara menyewa alat. Sedangkan penyangraian kopi masih manual yaitu menggunakan alat penggorengan biasa

2. Jenis Produksi

Kopi Robusta

3. Kapasitas Produksi

$20 \mathrm{~kg} /$ bulan

c. UMKM Langgeng

1. Peralatan Produksi

Peralatan untuk proses sangrai kopi masih manual yaitu menggunakan wajan dan bahan bakar dari kayu. 
Proses penggilingan dan penyaringan bubuk kopi sudah menggunakan mesin, akan tetapi mesin masih terbuat dari bahan logam sehingga dapat mempengaruhi kualitas dari kopi muria itu sendiri

2. Jenis Produksi

Kopi Robusta

3. Kapasitas Produksi

$100 \mathrm{~kg} / \mathrm{bulan}$

Berdasarkan hasil pengamatan di lapangan pada tiga UMKM kopi muria, dapat diketahui masalah-masalah yang mereka hadapi, sehingga belum mampu menjadikan kopi muria sebagai salah satu sumber penghasilan yang dapat diandalkan bagi masyarakat desa Colo khususnya dan masyarakat Kudus pada umumnya.

Tujuan kegiatan ini adalah memajukan UMKM kopi muria dengan melakukan edukasi kepada pelaku UMKM, difusi ipteks dengan pemberian mesin kopi, pelatihan pengolahan kopi dan perbaikan proses produksi kopi dari manual menjadi otomatis menggunakan mesin.

\section{METODE PELAKSANAAN}

Mitra UMKM Kopi Muria dalam kegiatan ini ada 3, yaitu, UMKM Wilhelmina, UMKM You Soeka, dan UMKM Langgeng. Kondisi dan permasalahan ketiga mitra ini berbeda, sebagaimana yang telah diuraikan pada bab pendahuluan. UMKM Kopi Muria dilakukan dengan cara: (1) Survey dan Sosialisasi (2) Pemberian mesin pengolah kopi, (3) Pelatihan pengolahan kopi.

\section{Survey dan Sosialisasi}

Kegiatan pengabdian kepada masyarakat ini didahului dengan survey dan sosialisasi kepada tiga mitra UMKM Kopi. Hasil survey pendahuluan dan wawancara dengan ketiga mitra, selama ini mengalami kendala dan permasalahan dalam pengolahan kopi dan pemasaran. Hal ini dijadikan dasar untuk merumuskan gambaran ipteks yang akan diransfer kepada mitra.

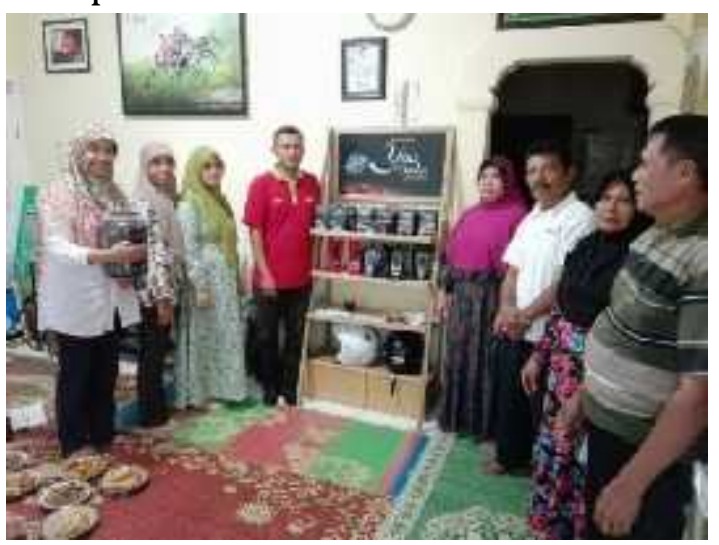

Gambar 1. Pelaksanaan Survey dan Sosialisasi kepada 3 mitra UMKM Kopi 
Di dalam acara survey dan sosialisasi ini juga diperagakan mengenai pengolahan kopi oleh mitra. Proses dimulai dari awal saat biji kopi masih berbentuk green been, proses penyangraian manual sampai dengan proses penggilingan biji kopi menjadi serbuk.

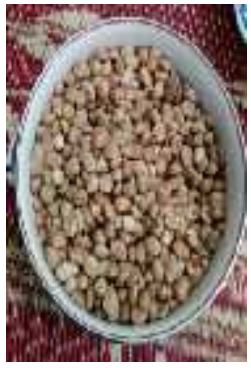

(a)

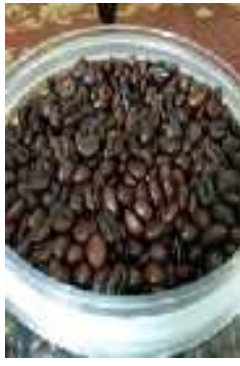

(b)

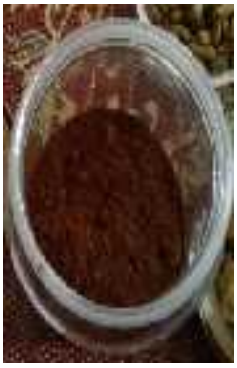

(c)

Gambar 2. Biji kopi sebelum dan sesudah diolah (a) Biji Kopi sebelum diroasting. (b) Biji Kopi setelah diroasting. (c) Biji Kopi setelah digiling.

\section{Difusi Ipteks: Pemberian Mesin Pengolah Kopi}

Hasil observasi dengan mitra 1, proses penyangraian sudah menggunakan mesin. Mesin yang dibutuhkan oleh mitra 1 adalah mesin grinder atau penepung kopi. Sehingga Tim pengabdian memberikan satu unit mesin grinder kopi untuk mitra 1.

Sedangkan mitra 2 dan 3 menunjukkan bahwa dalam mengolah kopi mereka masih menggunakan cara manual dalam menyangrai kopi yaitu dengan wajan dan kayu bakar. Kedua mitra belum memakai mesin roasting atau penyangrai untuk menyangrai kopi. Sehingga tim pengabdian memberikan masing-masing satu unit mesin roasting kopi untuk mitra 2 dan 3.

Pemberian mesin grinder kepada UMKM Wilhelmina, dapat dilihat pada gambar 3.

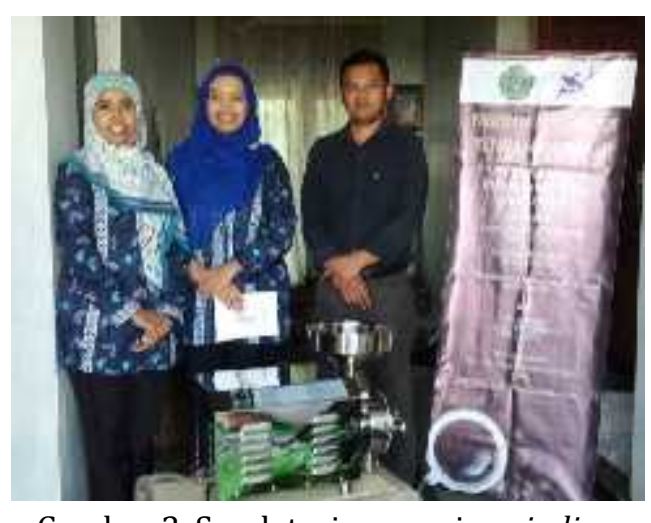

Gambar 3. Serah terima mesin grinding

Pemberian mesin roasting kepada UMKM You Soeka dan UMKM Langgeng dapat dilihat pada gambar 4 dan 5 . 


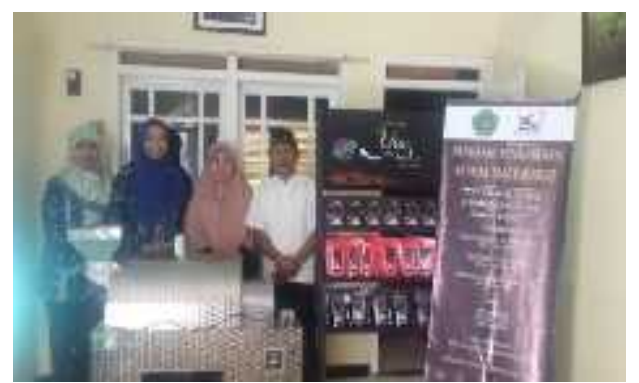

Gambar 4. Serah terima mesin roasting kepada UMKM Yoe Soeka

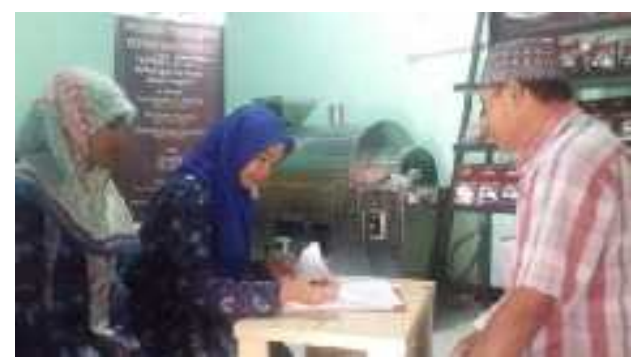

Gambar 5. Serah terima mesin roasting kepada UMKM Langgeng

\section{Pelatihan Pengolahan Kopi}

Kegiatan pelatihan pengolahan kopi diselenggarakan pada hari Jumat, 6 Juli 2018. Tempat pelatihan yaitu Balai Desa Colo Kecamatan Dawe Kabupaten Kudus. Narasumber dalam pelatihan kopi ini adalah Bapak Pranyoto Shofil. Beliau adalah pengusaha dan produsen kopi di wilayah Colo. Selain itu, narasumber adalah tokoh pelestari lingkungan dan pengurus Gapoktan Relung Muria untuk komoditas kopi di wilayah Kudus. Kegiatan pelatihan pengolahan kopi dapat dilihat pada Gambar 6.

Peserta pelatihan adalah para pemilik UKM di kelurahan setempat. Selain itu, pelatihan juga dihadiri oleh perangkat desa kelurahan Colo. Dalam pelatihan ini membahas mengenai beberapa topik, yaitu :
a) Ciri Kopi Muria dan karakteristiknya.
b) Cara mengidentifikasi biji kopi yang baik.
c) Cara menyortir biji kopi sebelum pengolahan.
d) Cara menyangrai kopi yang baik
e) Potensi Penjualan kopi
f) Diskusi permasalahan kopi

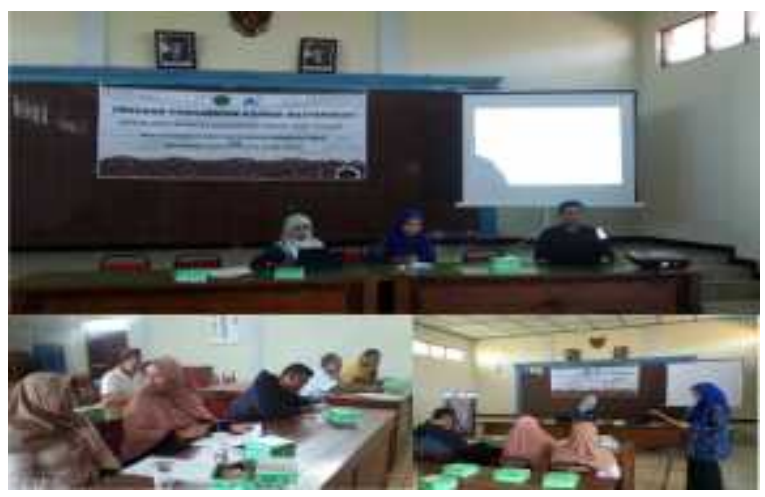

Gambar 6. Pelatihan pengolahan kopi 


\section{Pelatihan Pengolahan Kopi menggunakan Mesin Penyangrai}

Setelah acara pelatihan pengolahan kopi di balai desa Colo, diadakan kegiatan pelatihan pengolahan kopi menggunakan mesin roasting.Kegiatan ini bertempat di rumah mitra 1 UKM Yousoeka. Pada kegiatan ini diperagakan mengenai penyangraian biji kopi dengan mesin penyangrai tipe SGR-15 oleh narasumber Bapak Pranyoto Shofil.

Proses dimulai dari awal saat biji kopi masih berbentuk green been, pengaturan api, pengaturan suhu mesin, pengaturan putaran mesin, dan proses penyangraian kopi sampai biji kopi menjadi matang sempurna dan seragam. Kegiatan pelatihan pengolahan kopi menggunakan mesin roasting dapat dilihat pada Gambar 7.

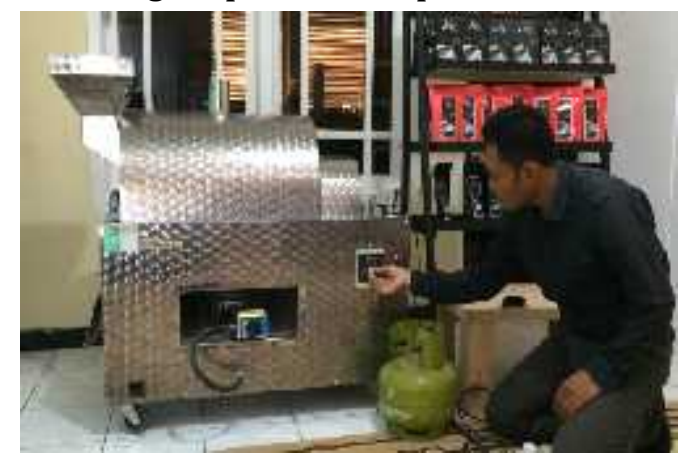

Gambar 7. Pelatihan pengolahan kopi menggunakan mesin roasting.

\section{HASIL DAN PEMBAHASAN}

Permasalahan yang dihadapi oleh mitra terletak pada proses produksi dan pemasaran. Sehingga solusi yang kita gunakan adalah sebagai berikut :

1. UMKM kopi muria diberikan edukasi tentang proses pengolahan kopi sampai dengan teknik pengemasan dan pemasaran. Pemberian edukasi ini dilakukan dalam bentuk pelatihan.

2. Pemberian mesin produksi berupa mesin roasting dan mesin grinding untuk meningkatkan kapasitas produksinya.

3. Melakukan pendampingan pada ketiga mitra dalam tata cara penggunaan mesin roasting dan mesin grinding kopi.

Tabel pengingkatan produktivitas kopi dapat dilihat pada Tabel 3. Sedangkan gambar alat produksi sebelum dan sesudah pemakaian mesin pengolah kopi dapat dilihat pada gambar 8 dan 9.

Tabel 3. Peningkatan produktivitas kopi

\begin{tabular}{ccc}
\hline Peningkatan & Sebelum & Setelah \\
\hline Alat Produksi & Wajan & Mesin \\
\hline Bahan baku & $3 \mathrm{~kg} / \mathrm{hari}$ & $15 \mathrm{~kg} / \mathrm{hari}$ \\
\hline Waktu Produksi & $3 \mathrm{~kg} / 2 \mathrm{jam}$ & $15 \mathrm{~kg} / 1 \mathrm{jam}$ \\
\hline
\end{tabular}

\section{Peningkatan Produktivitas Kopi}

Setelah UMKM Yousoeka dan UMKM Langgeng menggunakan mesin peyangrai kopi, didapatkan hasil peningkatan produksi sebagai berikut :

a) Peningkatan Bahan Baku : 
Sebelum : $3 \mathrm{~kg} / \mathrm{hari}$

Sekarang : $15 \mathrm{~kg} /$ hari

b) Mempercepat Waktu produksi

Sebelum : $3 \mathrm{~kg} / 2$ jam

Sekarang : $15 \mathrm{~kg} / 1$ jam

c) Peningkatan Produktivitas 5X lipat

Sebelum : $3 \mathrm{~kg} /$ hari

Sekarang : $15 \mathrm{~kg} / \mathrm{hari}$

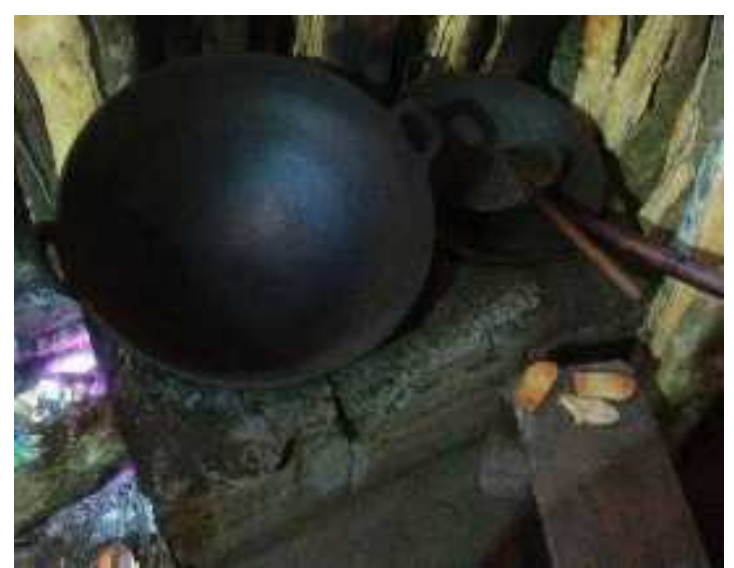

Gambar 8. Proses produksi (sebelum) masih menggunakan wajan dan tungku kayu bakar

\section{Peningkatan Kuantitas Produk Kopi}

Sebelumnya UMKM Kopi Yousoeka dan Langgeng hanya memproduksi $3 \mathrm{~kg}$ kopi per hari. Hal ini disebabkan karena proses penyangraian kopi secara manual memerlukan waktu lama, yaitu 2 jam. Selama proses penyangraian tersebut, biji kopi dalam wajan harus terus diaduk secara terus menerus agar tidak gosong. Hal ini merupakan keterbatasan tenaga bagi para UMKM kopi untuk memproduksi kopi dalam sehari.

Setelah menggunakan mesin peyangrai kopi, dalam sehari UMKM mampu menghasilkan kopi 15 kg kopi sehari. Dan proses ini dilakukan dalam waktu singkat yaitu 1 jam.

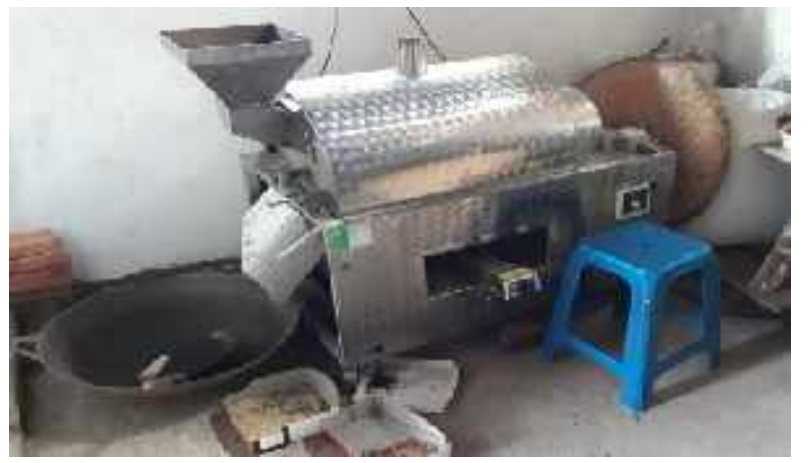

Gambar 9. Proses pengolahan kopi menggunakan mesin roasting.

\section{Peningkatan Kualitas Kopi}

Penggunaan mesin roasting kopi dalam proses penyangraian dapat membuat biji kopi menjadi seragam kematangannya. Hal ini karena mesin dapat diatur parameternya, 
yaitu : pengaturan api, pengaturan suhu, pengaturan putaran roaster. Sehingga proses penyangraian kopi sampai biji kopi menjadi matang sempurna dan seragam.

Penggunaan metode penyangraian yang berbeda, mempengaruhi cita rasa kopi. Begitu pula dengan keseragaman kematangan biji kopi pada saat penyangraian. Suhu saat penyangraian juga mempengaruhi tingkat keasaman dari seduhan kopi. (Irma Nopitasari, 2010). Oleh karena itu, proses penyangraian dengan mesin roasting dapat menunjang kualitas biji kopi. Proses penyangraian dapat diatur suhunya, dan dapat menghasilkan tingkat kematangan biji kopi yang seragam, sehingga dihasilkan kualitas kopi sangrai yang bagus.
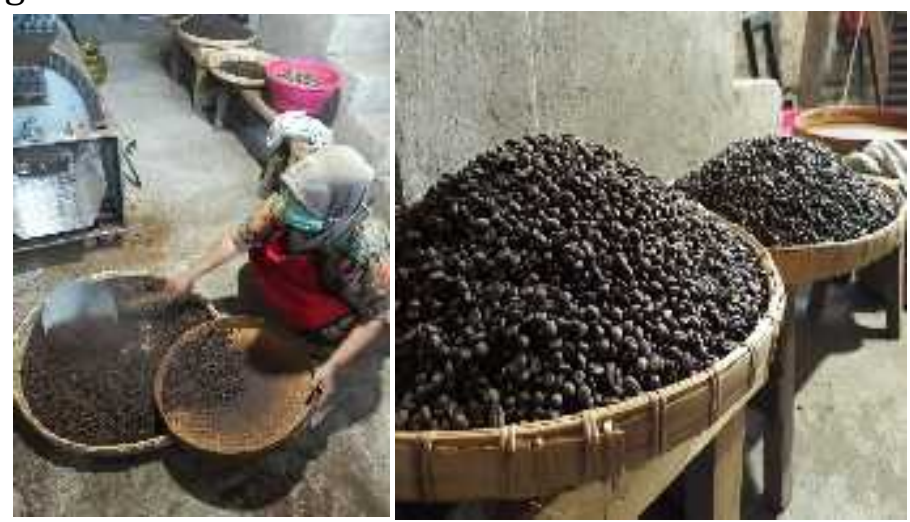

Gambar 10. Penyangraian kopi menggunakan mesin menghasilkan kematangan kopi

\section{SIMPULAN}

yang seragam

Dari hasil kegiatan pengabdian kepada para UMKM kopi muria ini, dapat disimpulkan sebagai berikut :

1. Peningkatan kapasitas produksi bagi UMKM Kopi Muria. Proses produksi yang tadinya dijalankan secara manual dan kapasitas kecil, telah meningkat menjadi diproses oleh mesin dengan kapasitas $5 \mathrm{x}$ lebih besar.

2. Peningkatan pengetahuan para produsen Kopi Muria khususnya mengenai cara pengolahan kopi yang baik untuk peningkatan kualitas kopi.

3. Peningkatan Sumber Daya Manusia (SDM).

4. Luaran kegiatan ini adalah meningkatnya produktivitas kopi muria melalui peningkatan kapasitas produksi dan kualitas kopi sehingga produk kopi muria ini dapat menjadi produk unggulan di Kabupaten Kudus

\section{UCAPAN TERIMA KASIH(Jika diperlukan)}

Ucapan terima kasih kami sampaikan kepada DRPM Kemenristekdikti yang telah mendanai program pengabdian kepada masyarakat yang kami laksanakan. Selain itu kami juga mengucapkan terima kasih kepada LPPM UNISNU Jepara yang telah mensupport secara penuh dalam program ini.

\section{DAFTAR RUJUKAN}

Chaffey, D., Chadwik, F.E., Johnston, K., Mayer, R. 2006. Internet Marketing Strategy Implementation and Practice. Prentice Hall: England. 
Hendra B., Farida R., Febriana S., 2015. Isolasi Dan Identifikasi Alkoloid Pada Biji Kopi Robusta (Coffea ROBUSTA Lindl. Ex De Will) dengan Cara Kromatografi Lapis Tipis. CERATA Journal Of Pharmacy Science. STIKES Muhammadiyah Klaten.

Irma N., 2010. Proses Pengolahan Kopi Bubuk (Campuran Arabika dan Robusta) serta Perubahan Mutunya Selama Penyimpanan. Skripsi sarjana S1 Fakultas Teknologi Pertanian: Institut Pertanian Bogor.

Ladjamudin A. 2005. Analisis dan Desain Sistem Informasi. Garaha Ilmu: Yogyakarta

Muhammad F.A. 2014. Analisis Keragaman Morfologi Koleksi Tanaman Kopi Arabika dan Robusta Balai Penelitian Tanaman Industri dan Penyegar Sukabumi. Skripsi sarjana S1 Fakultas Pertanian, Institut Pertanian Bogor.

Muhammad Ridwan Harahap. 2017. Identifikasi Daging Buah Kopi Robusta (Coffea Robusta) Berasal dari Provinsi Aceh. Elkawnie: Jurnal of Islamic Science and Technology Vol. 3, No. 2, Desember 2017 